J. Amer. Soc. Hort. Sci. 127(3):397-403. 2002.

\title{
Polyploidy-induced Changes in the Breeding Behavior of Hatiora $\times$ graeseri (Cactaceae)
}

\author{
Renate Karle, ${ }^{1}$ Constance A. Parks, ${ }^{2}$ Maureen C. O'Leary, ${ }^{1}$ and Thomas H. Boyle ${ }^{3}$ \\ Department of Plant and Soil Sciences, French Hall, University of Massachusetts, Amherst, MA 01003
}

\begin{abstract}
AdDitional INDEX wORDs. chromosomes, Easter cactus, isozymes, pollen tube growth, seed set, self-incompatibility, tetraploids
Abstract. Spontaneous chromosome doubling occurred in shoot apices of two diploid $(2 \mathrm{n}=22) \mathrm{Hatiora} \times$ graeseri Barthlott ex D. Hunt (Easter cactus) clones and yielded stable periclinal cytochimeras with a diploid epidermis and tetraploid subepidermis. The cytochimeras produced disomic gametes $(n=22)$ and displayed tetrasomic inheritance at polymorphic isozyme loci. Diploid clones were highly self-incompatible (SI) but both cytochimeras were self-compatible (SC). Analysis of pollen tube growth in selfed or outcrossed styles revealed that polyploidy altered the incompatibility phenotype of pollen without affecting the incompatibility phenotype of the pistil. Morphological data (guard cell length, stomatal density, and pollen diameter), segregation ratios at isozyme loci, and fruit/seed yields indicate that $S_{1}$ progeny are SC, nonchimeral, and tetraploid. Breakdown of the SI system in the cytochimeras was attributed to formation of compatible heteroallelic pollen. These results provide a rational explanation for the correlation between ploidy level and breeding behavior in cacti. Production of SC autotetraploid clones from SI diploids by chromosome doubling may be useful in development of cacti as fruit crops.
\end{abstract}

The Cactaceae comprises $\approx 1800$ species of succulent perennials with a base chromosome number of $\mathrm{x}=11$ (Anderson, 2001; Pinkava et al., 1999). Four Cactaceae subfamilies are recognized: Pereskioideae, Maihuenioideae, Opuntioideae, and Cactoideae (Anderson, 2001). Polyploidy is a common phenomenon in the Cactaceae (Pinkava et al., 1999) but the proportion of polyploid taxa varies markedly among the four subfamilies. Pereskioideae and Maihuenioideae taxa studied thus far are exclusively diploid $(2 \mathrm{n}=$ $2 \mathrm{x}=22$ ) (Leuenberger, 1986; Pinkava et al., 1999; Ross, 1981; Spencer, 1955), while 64.3\% of 199 taxa in Opuntioideae and $12.9 \%$ of 435 taxa in Cactoideae are polyploids (Pinkava et al., 1999).

Polyploids can originate by two processes: production and union of unreduced ( $2 n$ ) gametes in diploids, or chromosome doubling in somatic tissues, i.e., in the shoot apical meristem or zygote (de Wet, 1980; Harlan and de Wet, 1975; Thompson and Lumaret, 1992). Pinkava et al. (1999) and Ross (1981) proposed that most polyploid cacti originated by union of unreduced gametes. However, Remski (1954) hypothesized that some polyploid cacti may have arisen by chromosome doubling in apical meristems. Formation of polyploids via chromosome doubling in somatic tissues is considered to be a rare phenomenon in plants (de Wet, 1980; Harlan and de Wet, 1975).

Self-incompatibility (SI) is a genetically controlled mechanism that prevents self-fertilization in fertile hermaphroditic plants when they are selfed or crossed to another plant with an identical incompatibility phenotype (de Nettancourt, 2001). SI is prevalent in the Pereskioideae and Cactoideae (Boyle, 1997; Leuenberger, 1986; Ross, 1981) but is apparently rare in the Opuntioideae (Grant and Grant, 1981) and unknown in the Maihuenioideae. One-locus, gametophytic SI has been documented for two Cactoideae genera: Schlumbergera Lem. (Boyle, 1997) and Echinopsis Zucc. (Boyle and Idnurm, 2001).

Received for publication 17 Sept. 2001. Accepted for publication 8 Feb 2002. Massachusetts Agricultural Experiment Station publication no. 3306. This research was funded in part by the Cooperative State Research, Extension, Education Service, U.S. Department of Agriculture, Massachusetts Agricultural Experiment Station, under Project No. 746. We thank Michael Marcotrigiano, Jim Mauseth, and Yossi Mizrahi for informative discussions.

${ }^{1}$ Former graduate research assistant.

${ }^{2}$ Graduate research assistant.

${ }^{3}$ Professor and corresponding author; e-mail tboyle@pssci.umass.edu.
Self-compatibility (SC) is frequently encountered in artificially induced tetraploids or natural tetraploid relatives of diploid species with one-locus, gametophytic SI (de Nettancourt, 2001). Genera that contain SC tetraploids and SI diploid ancestors include Campanula L.(Gairdner, 1926), Nicotiana L.(Pandey, 1968), Oenothera L. (Lewis, 1947), Petunia Juss. (Stout and Chandler, 1942), Pyrus L. (Crane and Lewis, 1942), and Trifolium L. (Brewbaker, 1958; Pandey, 1956). The present research was conducted to examine the relationship between ploidy level and breeding behavior in Hatiora $\times$ graeseri (Cactaceae, subfamily Cactoideae).

\section{Materials and Methods}

Origin of PLANT Material. Two vegetatively propagated cultivars (H. × graeseri 'Evita' and 'Purple Pride') were obtained in January 1989 from J. de Vries Potplantencultures bv, Aalsmeer, The Netherlands. Both cultivars produced functional gametes and were highly SI (Boyle et al., 1994). Between 1989 and 1993, several hundred plants of each cultivar were grown in greenhouses at the Univ. of Massachusetts, Amherst. In 1990, a plant of 'Purple Pride' produced an atypical branch with flowers and phylloclades that were larger and thicker than those on other branches of the same plant or on other 'Purple Pride' plants. The atypical branch yielded seed-bearing fruit in the apparent absence of compatible pollinations. In 1991, an atypical branch was discovered on one plant of 'Evita'. This branch produced phylloclades and flowers that were larger than those on other branches of the same plant or on other 'Evita' plants, and yielded fruit containing viable seeds. Phylloclades were harvested from the atypical branches of 'Purple Pride' and 'Evita' and were propagated vegetatively. Hereafter, plants propagated from atypical phylloclades will be referred to as variant clones, whereas authentic cultivars and their clonal progeny will be referred to as original clones.

Flowers on the variant clones of 'Evita' and 'Purple Pride' were self-pollinated and the resulting seedlings were propagated vegetatively. Hereafter, these seedlings will be referred to as $S_{1}$ progeny of the variant clones.

Procedures used for growing plants were reported previously (Boyle et al., 1994). All crosses will be presented as pistillate parent $\mathrm{x}$ pollen parent.

Chromosome counts (EXPT. 1). Immature flower buds of the 
original and variant clones of 'Evita' and 'Purple Pride' were fixed in Carnoy's fluid [6 ethanol : 1 chloroform : 1 glacial acetic acid (by volume)] for $\approx 24 \mathrm{~h}$, transferred to $70 \%(\mathrm{v} / \mathrm{v})$ ethanol, and stored at $3{ }^{\circ} \mathrm{C}$. Anthers were dissected from buds and squashed in a drop of acetocarmine. Chromosome counts were obtained from a minimum of 10 intact pollen mother cells per clone.

EPIDERMAL AND POLLEN TRAITS (EXPT. 2). Four mature apical phylloclades were harvested from 6-month-old stock plants of original and variant clones of 'Evita' and 'Purple Pride' and $15 \mathrm{~S}_{1}$ progeny of each variant clone. One epidermal imprint was obtained from each phylloclade by applying clear fingernail polish to $\mathrm{a} \approx 1.5$ $\mathrm{cm}^{2}$ area between the midrib and edge and equidistant from the proximal and distal ends of the phylloclade (Sax, 1938). For each imprint, the numbers of stomates were counted in 10 randomly chosen microscope fields $\left(0.9331 \mathrm{~mm}^{2}\right.$ field area with $16 \times$ objective) and the lengths of 10 guard cells were measured.

Pollen was collected from original and variant clones of 'Evita' and 'Purple Pride' and $18 \mathrm{~S}_{1}$ progeny of each variant clone. Pollen was fixed in 3 ethanol : 1 glacial acetic acid (v/v) for $\geq 12 \mathrm{~h}$ and stained for $\approx 24 \mathrm{~h}$ in $0.5 \%(\mathrm{w} / \mathrm{v})$ aniline blue in lactophenol (Darlington and La Cour, 1942). The diameters of 50 pollen grains were measured for each original and variant clone, and 25 pollen grains were measured for each $\mathrm{S}_{1}$ progeny. Pollen stainability was assessed on 1,000 pollen grains per clone. Intensely stained grains were scored as viable whereas unstained or lightly stained grains were scored as nonviable.

BREEDING BEHAVIOR OF THE ORIGINAL AND VARIANT CLONES (EXPT.3). Budded plants of original and variant clones of 'Evita' and 'Purple Pride' were transferred from a greenhouse to a growth chamber maintained at $20 \pm 1{ }^{\circ} \mathrm{C}$ and providing a photosynthetic photon flux (400 to $700 \mathrm{~nm}$ ) of $50 \pm 8 \mu \mathrm{mol} \cdot \mathrm{s}^{-1} \cdot \mathrm{m}^{-2}$ for $12 \mathrm{~h}$ daily from cool-white fluorescent lamps. Flower buds were emasculated $\approx 1 \mathrm{~d}$ before anthesis and stigmatic lobes were washed with deionized water to dislodge adhering material. Flowers were pollinated 1 to $3 \mathrm{~d}$ after emasculation by rubbing recently dehisced anthers on the stigmatic lobes. Pistils were excised $72 \mathrm{~h}$ after pollination and fixed in 3 ethanol : 1 glacial acetic acid (v/v) for $\geq 24 \mathrm{~h}$. To observe pollen tube growth in the style and ovary, the ovary wall was cut away from two sides of each pistil to produce a median longitudinal section $(\approx 1 \mathrm{~mm}$ thick $)$ with the stigma and style remaining attached. Pistils were softened in $4 \mathrm{~N} \mathrm{NaOH}$ for $24 \mathrm{~h}$, stained with $0.1 \%(\mathrm{w} / \mathrm{v})$ decolorized aniline blue in $0.1 \mathrm{M} \mathrm{K}_{3} \mathrm{PO}_{4}$ (Martin, 1959), and examined using epifluorescence microscopy. A minimum of four pistils were examined per cross.

Plants of original and variant clones of 'Evita' and 'Purple Pride' were selfed and crossed in all possible pairwise combinations. Flower buds were emasculated and pollinated as described earlier. A minimum of 25 flowers were pollinated for each self or cross. Percentage fruit set was calculated and fruits were harvested at $120 \mathrm{~d}$ after pollination (DAP). Seeds were cleaned as described by Boyle (1994) and sown in covered glass petri dishes containing one layer of blue blotter paper (Anchor Paper Co., Charlotte, N.C.) moistened with deionized water. Dishes were sealed with parafilm (Amer. Natl. Can Co., Menasha, Wis.) and placed in a growth chamber providing the same temperature regime, irradiance, and photoperiod described previously. The number of germinated seeds (those with protruding radicles) were recorded for each fruit at $30 \mathrm{~d}$ after sowing.

ISOZYME ANALYSIS (EXPT. 4). Phylloclades were collected from the original and variant clones of 'Evita' and 'Purple Pride' plus $S_{1}$ seedlings of both variant clones ( 150 per $S_{1}$ family). Isozymes were extracted as described previously (O'Leary and Boyle, 1998b) and separated by electrophoresis using a Mini-Protean II cell (Bio-Rad Laboratories, Hercules, Calif.). Electrophoresis was performed at 4 ${ }^{\circ} \mathrm{C}$ under constant voltage $(200 \mathrm{~V})$. The electrode buffer was 0.025 M Tris and 0.2 m glycine ( $\mathrm{pH} 8.3$ ). 'Evita' variant and its $\mathrm{S}_{1}$ progeny were scored for triosephosphate isomerase (TPI, E.C. 5.3.1.1) and 'Purple Pride' variant and its $\mathrm{S}_{1}$ progeny were scored for phosphoglucomutase (PGM, E.C. 5.4.2.2). These enzyme systems were chosen because the original clones of 'Evita' and 'Purple Pride' were known to be polymorphic for Tpi-2 and Pgm-2, respectively (O'Leary and Boyle, 1999). Single-percentage polyacrylamide gels $[10 \%(\mathrm{w} / \mathrm{v})$ for TPI and 5\% (w/v) for PGM] were prepared with a $0.375 \mathrm{~m}$ Tris- $\mathrm{HCl}$ buffer, $\mathrm{pH} 8.8$ (Hames, 1981). The recipes of Wendel and Weeden (1989) were used for staining gels. Genotype frequencies were compared with ratios expected for tetrasomic inheritance (Weeden and Wendel, 1989).

Breeding Behavior of $S_{1}$ PROGeny (EXPT. 5). Intact (nonemasculated) flowers of 'Purple Pride' variant and $15 \mathrm{~S}_{1}$

Fig. 1. Photomicrographs of meiotic chromosomes of diploid (2x) and polyploid (4x) Hatiora $\times$ graeseri. (A) 'Evita' original clone, metaphase I, $\mathrm{n}=11$; (B) 'Evita' variant clone, anaphase I, $\mathrm{n}=22$; (C) 'Purple Pride' original clone, anaphase I, $\mathrm{n}=11$; (D) 'Purple Pride' variant clone, anaphase I, $\mathrm{n}=22$ (Expt. 1). Scale bars $=20 \mu \mathrm{m}$.
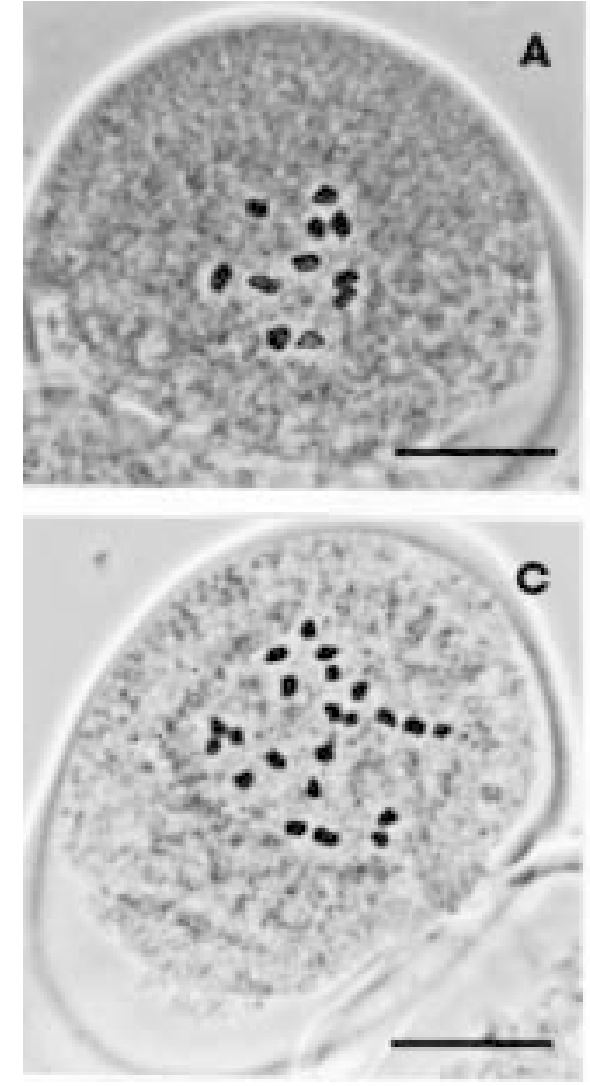

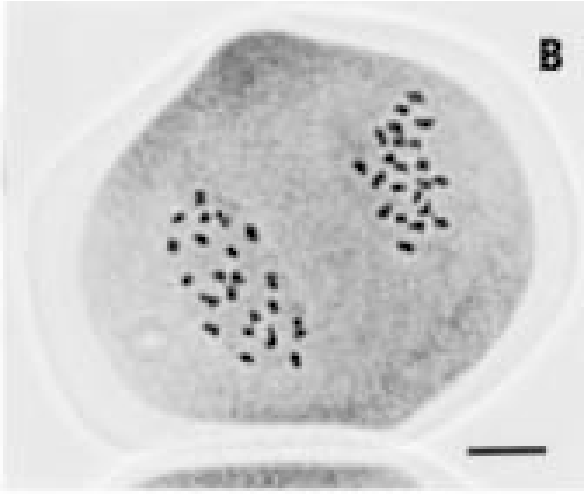

B

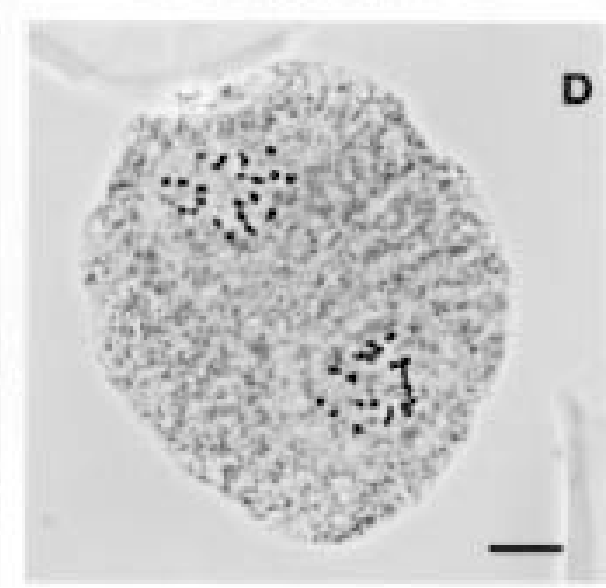


Table 1. Guard cell length and stomatal density for the original and variant clones of Hatiora $\times$ graeseri 'Evita' and $15 \mathrm{~S}_{1}$ progeny of the variant clone (Expt. 2).

\begin{tabular}{lcc}
\hline \hline Clone & $\begin{array}{c}\text { Guard cell length } \\
(\mu \mathrm{m})^{\mathrm{z}}\end{array}$ & $\begin{array}{r}\text { Stomatal density } \\
\left(\text { no. } / \mathrm{mm}^{2}\right)^{\mathrm{z}}\end{array}$ \\
\hline Original & 24.6 & 19.7 \\
Variant & 24.7 & 21.9 \\
$\mathrm{~S}_{1}-3$ & 30.0 & 9.1 \\
$\mathrm{~S}_{1}-4$ & 28.4 & 14.0 \\
$\mathrm{~S}_{1}-5$ & 30.4 & 9.5 \\
$\mathrm{~S}_{1}-6$ & 26.5 & 11.1 \\
$\mathrm{~S}_{1}-8$ & 31.2 & 11.3 \\
$\mathrm{~S}_{1}-9$ & 29.6 & 10.2 \\
$\mathrm{~S}_{1}-10$ & 28.0 & 9.3 \\
$\mathrm{~S}_{1}-11$ & 29.9 & 11.3 \\
$\mathrm{~S}_{1}-16$ & 31.2 & 9.7 \\
$\mathrm{~S}_{1}-17$ & 32.2 & 10.3 \\
$\mathrm{~S}_{1}-18$ & 30.5 & 9.8 \\
$\mathrm{~S}_{1}-19$ & 30.4 & 10.3 \\
$\mathrm{~S}_{1}-21$ & 31.2 & 12.7 \\
$\mathrm{~S}_{1}-22$ & 27.6 & 11.7 \\
$\mathrm{~S}_{1}-23$ & 30.2 & 11.9 \\
LSD $_{0.05}$ & 0.9 & 0.8
\end{tabular}

$\overline{\mathrm{z} V a l u e s}$ are means of four plants per clone and 10 measurements per plant $(\mathrm{n}=40)$.

progeny were selfed on the day of anthesis. Plants were maintained in a greenhouse and different clones were separated by a minimum distance of $0.5 \mathrm{~m}$. About 16 flowers were pollinated per clone. Fruit were harvested $\approx 120$ DAP and seeds were germinated as described earlier.

Data analysis. Guard cell length and stomatal density data (Expt. 2) were subjected to analysis of variance using the PROC ANOVA procedure of SAS (SAS Inst., Inc., Cary, N.C.). A hierarchical classification was used to separate clonal effects (variation among clones), sampling error (variation among measurements within phylloclades), and experimental error (variation among plants within clones). Percentage data (Expts. 2 and 3 ) and isozyme segregation ratios (Expt. 4) were analyzed using chi-square tests.

\section{Results and Discussion}

Chromosome counts (EXPT. 1). Flower buds ranging from 11 to $15 \mathrm{~mm}$ in length were found to be most suitable for meiotic chromosome counts. The original clones of 'Evita' and 'Purple Pride' were diploid ( $\mathrm{n}=11$; Fig. $1 \mathrm{~A}$ and $\mathrm{C})$ and the variant clones of 'Evita' and 'Purple Pride' were tetraploid ( $\mathrm{n}=22$; Fig. $1 \mathrm{~B}$ and D). These counts are consistent with the established base number of $\mathrm{x}$ $=11$ for the Cactaceae and Barthlott's (1976) count of $2 n=22$ for H. rosea (Lagerheim) Barthlott. Mitotic chromosome counts obtained from adventitious roots were $2 n=22$ for the original clones and $2 n=44$ for the variant clones (Parks, 2002). Thus, for each clone, the number of chromosomes in root (somatic) cells was in accordance with the number of chromosomes observed in pollen mother cells.

EPIDERMal AND POLlen TRAITs (EXPT. 2). The clones varied significantly $(P=0.001)$ in guard cell length, stomatal density, pollen diameter, and percentage stainable pollen. The original and variant clones produced smaller but more numerous stomates than the $S_{1}$ clones (Tables 1 and 2). However, pollen grains from the original clones were smaller than those from the variants or their $S_{1}$
Table 2. Guard cell length and stomatal density for the original and variant clones of Hatiora $\times$ graeseri 'Purple Pride' and $15 \mathrm{~S}_{1}$ progeny of the variant clone (Expt. 2).

\begin{tabular}{lcc}
\hline \hline Clone & $\begin{array}{r}\text { Guard cell length } \\
(\mu \mathrm{m})^{\mathrm{z}}\end{array}$ & $\begin{array}{c}\text { Stomatal density } \\
\left(\text { no. } / \mathrm{mm}^{2}\right)^{\mathrm{z}}\end{array}$ \\
\hline Original & 24.4 & 20.1 \\
Variant & 23.4 & 25.0 \\
$\mathrm{~S}_{1}-1$ & 26.5 & 12.5 \\
$\mathrm{~S}_{1}-3$ & 28.2 & 12.3 \\
$\mathrm{~S}_{1}-5$ & 29.3 & 11.6 \\
$\mathrm{~S}_{1}-6$ & 30.1 & 12.0 \\
$\mathrm{~S}_{1}-7$ & 28.9 & 13.1 \\
$\mathrm{~S}_{1}-8$ & 31.3 & 12.7 \\
$\mathrm{~S}_{1}-9$ & 30.9 & 11.0 \\
$\mathrm{~S}_{1}-10$ & 31.3 & 12.5 \\
$\mathrm{~S}_{1}-11$ & 31.8 & 11.9 \\
$\mathrm{~S}_{1}-12$ & 29.8 & 11.9 \\
$\mathrm{~S}_{1}-14$ & 32.5 & 11.0 \\
$\mathrm{~S}_{1}-16$ & 33.3 & 10.4 \\
$\mathrm{~S}_{1}-17$ & 30.4 & 11.2 \\
$\mathrm{~S}_{1}-18$ & 29.4 & 11.0 \\
$\mathrm{~S}_{1}-20$ & 29.9 & 12.6 \\
LSD $_{0.05}$ & 0.8 & 0.9 \\
\hline
\end{tabular}

${ }^{\mathrm{z} V}$ alues are means of four plants per clone and 10 measurements per plant $(\mathrm{n}=40)$.

progeny (Tables 3 and 4). There was a positive correlation between pollen diameter and the number of chromosomes in pollen mother cells for the original and variant clones (Tables 3 and 4; Fig. 1). Pollen stainability ranged from $96.8 \%$ to $99.2 \%$ for the original and variant clones, and from $86.0 \%$ to $99.7 \%$ for the $S_{1}$ progeny.

Polyploids typically produce larger but fewer stomata than their diploid counterparts (Li et al., 1996; Remski, 1954; Tal, 1980). Stomatal measurements for 'Evita' and 'Purple Pride' suggest that the original and variant clones have a lower ploidy level than the $S_{1}$ progeny clones (Tables 1 and 2). Chromosome counts and pollen diameter measurements, however, indicate that the original clones are diploid whereas the variants and their $S_{1}$ progeny are tetraploid (Fig. 1; Tables 3 and 4). The most plausible explanation for these findings is that the original clones are nonchimeral diploids and the variants are chimeras with a diploid epidermis and tetraploid subepidermis.

Shoot apical meristems of mature cacti consist of four distinct zones: a tunica, central mother cells, peripheral zone, and pith-rib meristem (Boke, 1941; Mauseth, 1978a, 1978b). The uniseriate tunica gives rise to the epidermis and the remainder of the stem is ultimately derived from the central mother cells (Boke, 1941). Therefore, shoot apical meristems of cacti consist of two independent histogens: a single-layered tunica (L-1) and the central mother cells, peripheral zone, and pith-rib meristem (L-2). Accordingly, two-layered apical meristems would yield only two types of periclinal cytochimeras, i.e., those with a polyploid epidermis and diploid subepidermis and those with a diploid epidermis and polyploid subepidermis. Both variant clones are of the latter type.

Since their discovery, the variant clones have undergone several cycles of vegetative propagation, but no revertants or new sports have been observed among daughter plants. The stability of the periclinal chimeras suggests that displacement of cells from the L1 to the L-2 (or vice versa) occurs infrequently.

BREEDING BEHAVIOR OF THE ORIGINAL AND VARIANT CLONES (EXPT. 3). By $72 \mathrm{~h}$ after pollination, pollen had germinated and 
pollen tubes had penetrated the stigmatic surface on selfed and outcrossed pistils. Few $(\leq 5)$ pollen tubes reached the base of the style when the original clones were selfed, but numerous pollen tubes ( $>70)$ traversed the style when the original clones were crossed reciprocally (Table 5). For the variants, many pollen tubes were observed at the base of the style following selfing or reciprocal crosses $(4 \mathrm{x} \times 4 \mathrm{x})$. Crossing the variant clones to their respective original clones resulted in large numbers $(>65)$ of pollen tubes at the base of the style when the original clones were used as maternal parents but few $(\leq 8)$ pollen tubes when the variants were the maternal parents. Also, numerous pollen tubes were observed at the base of the style when variant clones were crossed reciprocally with a dissimilar $2 x$ clone, i.e., 'Evita' variant $x$ 'Purple Pride' original or 'Purple Pride' variant $\mathrm{x}$ 'Evita' original.

The original clones failed to set fruit when selfed but numerous fruit with viable seeds were produced when the original clones were crossed reciprocally (Tables 6 and 7). In contrast, the variant clones yielded fruit with viable seeds following selfing or reciprocal crosses $(4 \mathrm{x} x 4 \mathrm{x})$. Generally, $2 \mathrm{x} \times 2 \mathrm{x}$ crosses yielded more fruit with greater numbers of viable seeds than $4 \mathrm{x} \times 4 \mathrm{x}$ crosses (Tables 6 and $7)$. Crosses between the variant clones and their respective original clones were unsuccessful with the variants as maternal parents, but the reciprocal crosses yielded fruit (Table 6). A few viable seeds were obtained for the cross 'Evita' original $x$ 'Evita' variant, but the cross 'Purple Pride' original x 'Purple Pride' variant did not yield viable seeds (Table 7).

Results of Expt. 3 indicate that the SI system was fully functional in the two diploid (original) clones but was dysfunctional in the two chimeral (variant) clones, thus resulting in SC. We hypothesize that the SI system became incapacitated in both 'Evita' and 'Purple

Table 3. Pollen diameter and stainability for the original and variant clones of Hatiora $\times$ graeseri 'Evita' and $18 \mathrm{~S}_{1}$ progeny of the variant clone (Expt. 2).

\begin{tabular}{lcc}
\hline \hline & $\begin{array}{r}\text { Pollen diam } \\
(\mu \mathrm{m})^{\mathrm{z}}\end{array}$ & $\begin{array}{c}\text { Stainable pollen } \\
(\%)^{\mathrm{y}}\end{array}$ \\
\hline Orone & 59.6 & 98.3 \\
Variant & 81.5 & 96.8 \\
$\mathrm{~S}_{1}-3$ & 86.9 & 93.2 \\
$\mathrm{~S}_{1}-5$ & 88.6 & 89.2 \\
$\mathrm{~S}_{1}-6$ & 89.0 & 96.0 \\
$\mathrm{~S}_{1}-7$ & 94.1 & 88.2 \\
$\mathrm{~S}_{1}-8$ & 89.2 & 88.9 \\
$\mathrm{~S}_{1}-9$ & 90.1 & 87.2 \\
$\mathrm{~S}_{1}-10$ & 89.4 & 89.9 \\
$\mathrm{~S}_{1}-11$ & 89.3 & 94.8 \\
$\mathrm{~S}_{1}-13$ & 92.0 & 93.4 \\
$\mathrm{~S}_{1}-17$ & 90.4 & 88.0 \\
$\mathrm{~S}_{1}-19$ & 88.2 & 96.6 \\
$\mathrm{~S}_{1}-20$ & 87.6 & 92.9 \\
$\mathrm{~S}_{1}-21$ & 90.7 & 89.2 \\
$\mathrm{~S}_{1}-23$ & 88.2 & 95.0 \\
$\mathrm{~S}_{1}-25$ & 90.6 & 92.4 \\
$\mathrm{~S}_{1}-26$ & 85.4 & 90.7 \\
$\mathrm{~S}_{1}-27$ & 94.2 & 91.5 \\
$\mathrm{~S}_{1}-29$ & 93.7 & 86.0 \\
$\mathrm{LSD}_{0.05}$ & 2.8 & -- \\
$\chi^{2}$ test & --- & $* * *$ \\
\hline
\end{tabular}

${ }^{\mathrm{z}}$ For the original and variant clones $\mathrm{n}=50 ; \mathrm{n}=25$ for $\mathrm{S}_{1}$ clones.

yPollen stained with $0.5 \%(\mathrm{w} / \mathrm{v})$ aniline blue in lactophenol $(\mathrm{n}=1,000)$.

*** Differences among clones significant at $P \leq 0.001$ by heterogeneity chi-square test.
Pride' as a consequence of polyploidy. This hypothesis is consistent with several other studies demonstrating SC among artificially induced tetraploids or natural tetraploid relatives of diploid species with one-locus, gametophytic SI (Brewbaker, 1958; Crane and Lewis, 1942; Gairdner, 1926; Lewis, 1947; Pandey, 1956, 1968; Stout and Chandler, 1942).

Ross (1981) determined the ploidy level and breeding system (SI or SC) for 55 Cactaceae taxa. He found that breeding behavior was correlated with ploidy level, with SI occurring in $89 \%$ of diploids but only $34 \%$ of polyploids. Our findings shed some light on the correlation between ploidy level and breeding behavior in cacti. The correlation exists because SI, which occurs in many diploid taxa in the Cactoideae (Boyle, 1997), is disabled in their polyploid derivatives.

Relatively few pollen tubes were observed at the base of the style when an original clone was selfed or a variant clone was crossed as a female with its respective original clone, but numerous pollen tubes traversed the style when a variant clone was selfed or an original clone was crossed (as female) with its respective variant (Table 5). These observations indicate that polyploidy modified the incompatibility phenotype of the pollen but did not alter the pistil's incompatibility phenotype. In species with one-locus gametophytic SI, recently formed autotetraploids will be heterozygous $\left(S_{a} S_{a} S_{b} S_{b}\right)$ at the $\mathrm{S}$ locus and will yield homozygous $\left(S_{a} S_{a}\right.$ or $\left.S_{b} S_{b}\right)$ and heterozygous $\left(S_{a} S_{b}\right)$ pollen grains. Diploids of Pyrus communis L. (Rosaceae) and Lycopersicon peruvianum L. (Mill.) (Solanaceae) exhibit one-locus, gametophytic SI, but autotetraploids of both species are semicompatible, with the heterozygous pollen grains eliciting compatible responses and the homozygous grains showing incompatible responses following selfing (Lewis and Modlibowska,

Table 4. Pollen diameter and stainability for the original and variant clones of Hatiora $\times$ graeseri 'Purple Pride' and $18 \mathrm{~S}_{1}$ progeny of the variant clone (Expt. 2).

\begin{tabular}{lcc}
\hline \hline Clone & $\begin{array}{c}\text { Pollen diam } \\
(\mu \mathrm{m})^{\mathrm{z}}\end{array}$ & $\begin{array}{c}\text { Stainable pollen } \\
(\%)^{\mathrm{y}}\end{array}$ \\
\hline Original & 64.5 & 99.1 \\
Variant & 77.8 & 99.2 \\
$\mathrm{~S}_{1}-1$ & 82.1 & 98.2 \\
$\mathrm{~S}_{1}-2$ & 73.0 & 97.5 \\
$\mathrm{~S}_{1}-3$ & 82.3 & 99.7 \\
$\mathrm{~S}_{1}-4$ & 80.6 & 98.5 \\
$\mathrm{~S}_{1}-6$ & 78.6 & 98.7 \\
$\mathrm{~S}_{1}-7$ & 81.7 & 99.0 \\
$\mathrm{~S}_{1}-8$ & 74.2 & 97.6 \\
$\mathrm{~S}_{1}-9$ & 81.0 & 99.6 \\
$\mathrm{~S}_{1}-10$ & 75.7 & 96.8 \\
$\mathrm{~S}_{1}-11$ & 77.5 & 97.0 \\
$\mathrm{~S}_{1}-12$ & 83.0 & 96.1 \\
$\mathrm{~S}_{1}-13$ & 85.7 & 98.3 \\
$\mathrm{~S}_{1}-14$ & 78.0 & 97.9 \\
$\mathrm{~S}_{1}-15$ & 76.1 & 99.2 \\
$\mathrm{~S}_{1}-16$ & 78.5 & 96.9 \\
$\mathrm{~S}_{1}-17$ & 75.8 & 95.1 \\
$\mathrm{~S}_{1}-18$ & 77.2 & 96.5 \\
$\mathrm{~S}_{1}-19$ & 77.6 & 97.6 \\
$\mathrm{LSD}_{0.05}$ & 2.5 & --- \\
$\chi^{2}$ test & --- & $* * *$ \\
\hline
\end{tabular}

${ }^{\mathrm{z}}$ For the original and variant clones $\mathrm{n}=50 ; \mathrm{n}=25$ for $\mathrm{S}_{1}$ clones.

yollen stained with $0.5 \%(\mathrm{w} / \mathrm{v})$ aniline blue in lactophenol $(\mathrm{n}=1,000)$.

${ }^{* * *}$ Differences among clones significant at $P \leq 0.001$ by heterogeneity chi-square test. 
Table 5. Number of pollen tubes observed at the base of styles $72 \mathrm{~h}$ after crossing or selfing of the original ( $2 \mathrm{x})$ and variant (4x) clones of Hatiora $\times$ graeseri 'Evita' (EV) and 'Purple Pride' (PP) (Expt. 3). Values in parentheses indicate the number of styles examined for each self or cross.

\begin{tabular}{lcccc}
\hline & & \multicolumn{3}{c}{ Male parent } \\
\cline { 2 - 5 } Female parent & EV 2x & EV 4x & PP 2x & $>100(6)$ \\
EV 2x & $4.8 \pm 2.3^{\mathrm{z}}(6)$ & $>65(8)$ & $>60(4)$ & $>100(6)$ \\
EV 4x & $5.2 \pm 4.2(6)$ & $>100(7)$ & $1.5 \pm 1.7(8)$ & $>100(10)$ \\
PP 2x & $>70(5)$ & $>80(4)$ & $1.4 \pm 2.6(11)$ & $>80(6)$ \\
PP 4x & $>80(7)$ & $>120(10)$ & $>100(10)$ \\
\hline
\end{tabular}

${ }_{\mathrm{z}}$ Mean \pm SD when few $(<10)$ pollen tubes were present; otherwise, the minimum number of pollen tubes that were observed.

Table 6. Percentage fruit set following crossing or selfing of the original ( $2 \mathrm{x})$ and variant $(4 \mathrm{x})$ clones of Hatiora $\times$ graeseri 'Evita' (EV) and 'Purple Pride' (PP) (Expt. 3). Values in parentheses indicate the number of flowers pollinated per cross or self.

\begin{tabular}{lcccc}
\hline & & \multicolumn{3}{c}{ Male parent } \\
\cline { 2 - 5 } Female parent & EV 2x & EV 4x & PP 2x \\
\hline EV 2x & $0^{z}(26)$ & $24^{*}(25)$ & $87^{*}(31)$ & $3(30)$ \\
EV 4x & $0(28)$ & $26^{*}(27)$ & $0(29)$ & $3(29)$ \\
PP 2x & $37^{*}(30)$ & $43^{*}(28)$ & $0(26)$ & $4(28)$ \\
PP 4x & $68^{*}(31)$ & $37^{*}(30)$ & & $39^{*}(28)$ \\
\hline
\end{tabular}

${ }^{\mathrm{z}}$ Data collected $120 \mathrm{~d}$ after pollination.

* Significantly different from $0 \%$ fruit set by chi-square test, $P=0.05$.; $\chi^{2}=3.84$ for $1 \mathrm{df}$.

Table 7. Number of viable (germinated) seeds per fruit from crossing or selfing of the original $(2 \mathrm{x})$ and variant $(4 \mathrm{x})$ clones of Hatiora $\times$ graeseri 'Evita' (EV) and 'Purple Pride' (PP) (Expt. 3). Values in parentheses indicate the number of fruit used for germination experiments.

\begin{tabular}{lcccc}
\hline & \multicolumn{3}{c}{ Male parent } \\
\cline { 2 - 5 } Female parent & EV 2x & EV 4x & PP 2x & $100.6 \pm 22.0(10)$ \\
\hline EV 2x & ND $^{\mathrm{z}}$ & $0.8 \pm 1.0^{\mathrm{y}}(6)$ & $8(1)$ & PP 4x \\
EV 4x & ND & $10.6 \pm 5.2(7)$ & ND & ND \\
PP 2x & $93.6 \pm 14.9(10)$ & $1.0 \pm 1.1(10)$ & $0(1)$ & $66.4 \pm 29.3(10)$ \\
PP 4x & $35.7 \pm 7.2(10)$ & $53.3 \pm 21.5(10)$ &
\end{tabular}

${ }^{\mathrm{z}} \mathrm{ND}=$ no data due to absence of fruit set.

${ }^{y}$ Mean \pm SD. Data collected $30 \mathrm{~d}$ after seed sowing.

Table 8. Genotypic frequencies of $\mathrm{S}_{1}$ progeny of the variant $(4 \mathrm{x})$ clones of Hatiora $\times$ graeseri 'Evita' (EV) and 'Purple Pride' (PP). Segregation ratios are those expected from selfing balanced heterozygotes $(a a b b)$ with tetrasomic inheritance (Expt. 4).

\begin{tabular}{|c|c|c|c|c|c|c|c|c|c|}
\hline \multirow[b]{2}{*}{ Locus } & \multirow{2}{*}{$\begin{array}{l}\text { Parent } \\
\text { clone }\end{array}$} & \multirow{2}{*}{$\begin{array}{c}\text { Parent } \\
\text { genotype }\end{array}$} & \multicolumn{3}{|c|}{$\mathrm{S}_{1}$ progeny genotypes } & \multicolumn{2}{|c|}{$\begin{array}{c}\text { Chromatidal } \\
\text { segregation } \\
(9: 178: 9)\end{array}$} & \multicolumn{2}{|c|}{$\begin{array}{c}\text { Chromosomal } \\
\text { segregation } \\
(1: 34: 1)\end{array}$} \\
\hline & & & aaaa & $a \_b \_$ & $b b b b$ & $\chi^{2}$ & $P$ & $\chi^{2}$ & $P$ \\
\hline$\overline{T p i-2}$ & EV 4x & $a a b b$ & 0 & 145 & 5 & 7.99 & $0.01-0.02$ & 4.43 & $0.20-0.10$ \\
\hline$P g m-2$ & PP $4 x$ & $a a b b$ & 6 & 133 & 11 & 2.63 & $0.20-0.30$ & 12.29 & $0.001-0.01$ \\
\hline
\end{tabular}

1942; Chawla et al., 1997). We postulate that a similar phenomenon occurs in $H$. × graeseri.

Some viable seeds were obtained from interploidy crosses $(4 \mathrm{x} x$ $2 \mathrm{x}$ and $2 \mathrm{x} \times 4 \mathrm{x}$ ) between 'Evita' and 'Purple Pride' (Table 7). Generally, $4 \mathrm{x} \times 2 \mathrm{x}$ crosses were more successful than $2 \mathrm{x} \times 4 \mathrm{x}$ crosses, and more fruit was set with 'Purple Pride' as the maternal parent than with 'Evita' (Table 6). Among the four interploidy crosses that were made, 'Purple Pride' variant $(4 \mathrm{x}) \mathrm{x}$ 'Evita' original (2x) yielded the most fruit and the greatest number of viable seeds per fruit. Progeny from $4 \mathrm{x} \times 2 \mathrm{x}$ crosses would be expected to be primarily triploid ( $3 \mathrm{x}$ ). Triploids occur in several Opuntioideae taxa but have been reported in only one Cactoideae taxon: $x$ Myrtgerocactus lindsayi Moran, a naturally occurring intergeneric hybrid (Anderson, 2001; Pinkava and Parfitt, 1982; Pinkava et al., 1977, 1985, 1999).
ISOZYME ANALYSIS (EXPT. 4). 'Evita' original and 'Evita' variant were heterozygous at $T p i-2$ and their Tpi-2 genotypes were $a b$ and $a a b b$, respectively. $S_{1}$ progeny of 'Evita' variant produced single- or triple-banded patterns at Tpi-2. The genotypic frequencies for $S_{1}$ progeny of 'Evita' variant did not differ significantly from a 1:34:1 (aaaa $\left.: a b_{2}: b b b b\right)$ ratio that would be expected for an autotetraploid with chromosomal segregation (Table 8 ). The original and variant clones of 'Purple Pride' produced a double-banded phenotype at $P g m-2$, so their $P g m-2$ genotypes would thus be $a b$ and $a a b b$, respectively. $S_{1}$ progeny of 'Purple Pride' variant produced either single- or double-banded patterns at $P g m-2$. The $P g m-2$ segregation ratio obtained for $S_{1}$ progeny of 'Purple Pride' variant did not deviate significantly from a 9:178:9 (aaaa: $\left.a \_b \_: b b b b\right)$ ratio expected for an autotetraploid with chromatidal segregation (Table 8).

Selfing an autotetraploid balanced heterozygote $(a a b b)$ is ex- 
Table 9. Fruit and seed yields for Hatiora $\times$ graeseri 'Purple Pride' variant $(4 x)$ and 15 of its $S_{1}$ progeny. Flowers were selfed on the day of anthesis (Expt. 5).

\begin{tabular}{lcc}
\hline \hline Clone & $\begin{array}{c}\text { Fruit set } \\
(\%)^{\mathrm{z}}\end{array}$ & $\begin{array}{c}\text { No. viable } \\
\text { seeds/fruit }\end{array}$ \\
\hline Variant & 100 & 95.4 \\
$\mathrm{~S}_{1}-2$ & 88 & 36.6 \\
$\mathrm{~S}_{1}-3$ & $65^{*}$ & 47.0 \\
$\mathrm{~S}_{1}-4$ & 85 & 61.8 \\
$\mathrm{~S}_{1}-6$ & 83 & 22.2 \\
$\mathrm{~S}_{1}-8$ & 88 & 47.2 \\
$\mathrm{~S}_{1}-9$ & 95 & 54.0 \\
$\mathrm{~S}_{1}-10$ & 85 & 11.4 \\
$\mathrm{~S}_{1}-11$ & 94 & 45.2 \\
$\mathrm{~S}_{1}-12$ & $44^{*}$ & 16.2 \\
$\mathrm{~S}_{1}-13$ & 94 & 42.4 \\
$\mathrm{~S}_{1}-14$ & 82 & 48.4 \\
$\mathrm{~S}_{1}-15$ & $75^{*}$ & 32.8 \\
$\mathrm{~S}_{1}-16$ & 85 & 47.0 \\
$\mathrm{~S}_{1}-18$ & $73^{*}$ & 26.6 \\
$\mathrm{~S}_{1}-19$ & 100 & 29.2 \\
LSD & --05 & 15.5 \\
\hline
\end{tabular}

${ }^{\mathrm{z}}($ No. fruit set/no. flowers pollinated $) \times 100$. Data collected $120 \mathrm{~d}$ after pollination.

"Clone significantly different from 'Purple Pride' variant by chi-square test. $\chi^{2}=3.84$ for $1 \mathrm{df}$.

pected to yield 0.06 homozygotes (aaaa and $b b b b$ ) assuming chromosomal segregation and 0.092 homozygotes with chromatidal segregation (Weeden and Wendel, 1989). Chromosomal and chromatidal segregation, however, represent only two theoretical extremes in gametic output for autotetraploids. Chromosomal segregation assumes that bivalents always form or that the locus in question is inseparably linked with the centromere; under either scenario, sister chromatids never end up in the same gamete. Chromatidal segregation assumes that quadrivalents always form and a chiasma invariably develops between the locus in question the centromere; the net effect is that sister chromatids can end up in the same gamete. When quadrivalents occasionally form and the centromere and locus in question are partially linked, some gametes will contain sister chromatids but they will be rarer than predicted by chromatidal segregation. Hence, the expected proportion of homozygous progeny from selfing a balanced heterozygote is between 0.06 and 0.092 . Although the segregation ratios at Pgm-2 and Tpi2 were dissimilar, the genotypic frequencies at both loci are clearly indicative of tetrasomic inheritance (Table 8).

Hatiora $\times$ graeseri is an interspecific hybrid of $H$. gaertneri (Regel) Barthlott and $H$. rose $a$ that arose from deliberate crosses in the 1930s (Werdermann, 1939). The parental species occur in the same general area in southeastern Brazil but are likely to be reproductively isolated due to different altitudinal ranges, i.e., 350 to $1300 \mathrm{~m}$ for $H$. gaertneri and 1000 to $3000 \mathrm{~m}$ for $H$. rosea (Barthlott and Taylor, 1995; N.P. Taylor, personal communication). Diploid $H . \times$ graeseri clones have high $(>80 \%)$ pollen fertility (T.H. Boyle, unpublished research) and generally display simple inheritance patterns at isozyme loci (O'Leary and Boyle, 1998b). Also, the isozyme data for $4 \times \mathrm{H}$. $\times$ graeseri (Table 8 ) are indicative of autotetraploid segregation. These data suggest that $H$.gaertneri and $H$. rosea are closely related taxa that share a high degree of chromosome homology.

Breeding behavior of $\mathbf{S}_{\mathbf{1}}$ Progeny (ExPT. 5). All $\mathrm{S}_{1}$ progeny clones produced viable seeds when selfed, but there were significant differences among the $S_{1}$ clones in percentage fruit set and number of viable seeds per fruit (Table 9). Some $S_{1}$ progeny set fewer fruit and all $S_{1}$ progeny produced fewer viable seeds than 'Purple Pride' variant (Table 9).

The variants produce disomic gametes $(n=22)$ and therefore would be expected to yield $4 \times S_{1}$ progeny. Meiosis was not observed in the $S_{1}$ progeny clones, but stomatal density and pollen diameter measurements (Tables 1,2,3, and 4), segregation ratios at isozyme loci (Table 8), and selfing tests (Table 9) indicate that the $S_{1}$ progeny are SC, nonchimeral, and tetraploid.

Reduced pollen stainability and lower seed yields in $\mathrm{S}_{1}$ progeny may have been due to meiotic irregularities associated with polyploidy (Tables 3, 4, and 9). Species with tetrasomic inheritance do not display strict bivalent pairing but instead form multivalents and univalents. Univalents and trivalents can segregate in unbalanced numbers at anaphase I disjunction (Jackson, 1976), leading to formation of aneuploid gametes with fewer or more than the expected number of chromosomes. Disparity in seed yields between 'Purple Pride' variant and its $S_{1}$ progeny suggests that inbreeding depression may have also reduced fertility in $4 \mathrm{x} \mathrm{H}$. × graeseri. Autotetraploids originating from chromosome doubling in somatic cells are likely to exhibit more inbreeding depression than autotetraploids arising from union of unreduced gametes $(2 n+2 n)$ due to a lower degree of heterozygosity (Bever and Felber, 1992) and a greater genetic load (Thompson and Lumaret, 1992).

BotaNICAL SIGNIFICANCE. SI is widespread in the Cactaceae and has been documented in eight of the nine Cactoideae tribes (see Boyle, 1997). Evidence from genetic investigations (Boyle, 1997; Boyle and Idnurm, 2001), isozyme studies (Boyle and Idnurm, 2001; O'Leary and Boyle, 1998a), and examination of pollen tubes in selfed and outcrossed pistils (Boyle, 1996; Boyle et al., 1994) suggests that SI in cacti is gametophytic and controlled by a single multiallelic $(S)$ gene. The SC breeding behavior exhibited by the variant and $S_{1}$ progeny clones (Tables 5 and 9) provides additional support for presence of gametophytic monofactorial SI in the Cactaceae. Interestingly, cacti have tricellular pollen (Brewbaker, 1967) and papillate stigmas with little or no stigmatic exudate (Boyle, 1997; Boyle et al., 1994, 1995; Buxbaum, 1953). These two traits are characteristic of sporophytic SI rather than gametophytic SI (de Nettancourt, 2001). To our knowledge, the Cactaceae is the only angiosperm family known to have gametophytic monofactorial SI and tricellular pollen.

Horticultural SIGNIFICANCE. Numerous Cactaceae species are cultivated as fruit crops in tropical and subtropical regions of the world (Mizrahi et al., 1997). Some fruit-bearing species, such as Hylocereus costaricensis (F.A.C. Weber) Britton \& Rose and $H$. polyrhizus (F.A.C. Weber) Britton \& Rose, are diploid $(2 n=22)$ and highly SI (Lichtenzveig et al., 2000; Weiss et al., 1994; Tel-Zur et al., 2001). In Israel, flowers of $H$. costaricensis and $H$. polyrhizus must be hand pollinated during the morning because they open for one night and close by noon the following day, and available pollinators [e.g., honeybees (Apis mellifera L.)] are incapable of ensuring adequate yields of marketable fruit (Weiss et al., 1994). Additionally, compatible pollen must be collected and applied to stigmas due to the presence of SI. Pollen collection and hand pollination are time-consuming procedures and increase production costs. One possible means of minimizing costs for producing fruit of cacti like $H$. costaricensis and $H$. polyrhizus is to develop SC autotetraploid clones that are less dependent on biotic pollinators for fruit set. Autotetraploid cacti may also yield larger fruit than their diploid counterparts, a phenomenon reported in many other fruitbearing species (Sanford, 1983). Floral morphology may be an 
important criterion to consider when selecting diploid clones for induction of tetraploidy. Tetraploid SC clones displaying extreme herkogamy (spatial separation between anthers and stigma) may yield few and/or small fruits if flowers remain undisturbed. Clones exhibiting the least herkogamy would be more likely to produce acceptable yields if pollinator activity is low or absent.

\section{Literature Cited}

Anderson, E.F. 2001. The cactus family. Timber Press, Portland, Ore.

Barthlott, W. 1976. IOBP chromosome number reports LIV. Taxon 25:631-649.

Barthlott, W. and N.P. Taylor. 1995. Notes towards a monograph of Rhipsalideae. Bradleya 13:43-79.

Bever, J.D. and F. Felber. 1992. The theoretical population genetics of autopolyploidy. Oxford Surveys Evolutionary Biol. 8:185-217.

Boke, N.H. 1941. Zonation in the shoot apices of Trichocereus spachianus and Opuntia cylindrica. Amer. J. Bot. 28:656-664.

Boyle, T.H. 1994. A simple method for extracting and cleaning seeds of Rhipsalidopsis and Schlumbergera (Cactaceae). HortTechnology 4:264-265.

Boyle, T. 1996. Characteristics of self-incompatibility in Schlumbergera truncata and S. ×buckleyi (Cactaceae). Sexual Plant Reproduction 9:49-53.

Boyle, T.H. 1997. The genetics of self-incompatibility in the genus Schlumbergera (Cactaceae). J. Hered. 88:209-214.

Boyle, T.H. and A. Idnurm. 2001. Physiology and genetics of self-incompatibility in Echinopsis chamaecereus (Cactaceae). Sexual Plant Reproduction 13:323-327.

Boyle, T.H., R. Karle, and S.S. Han. 1995. Pollen germination, pollen tube growth, fruit set, and seed development in Schlumbergera truncata and $S$. $\times$ buckleyi (Cactaceae). J. Amer. Soc. Hort. Sci. 120:313-317.

Boyle, T.H., F.D. Menalled, and M.C. O'Leary. 1994. Occurrence and physiological breakdown of self-incompatibility in Easter cactus. J. Amer. Soc. Hort. Sci. 119:1060-1067.

Brewbaker, J.L. 1958. Self-incompatibility in tetraploid strains of Trifolium hybridum. Hereditas 44:547-553.

Brewbaker, J.L. 1967. The distribution and phylogenetic significance of binucleate and trinucleate pollen grains in the angiosperms. Amer. J. Bot. 54:10691083.

Buxbaum, F. 1953. Morphology of cacti. Section II. The flower. Abbey Garden Press, Pasadena, Calif.

Chawla, B., R. Bernatzky, W. Liang, and M. Marcotrigiano. 1997. Breakdown of self-incompatibility in tetraploid Lycopersicon peruvianum: Inheritance and expression of $S$-related proteins. Theoretical Appl. Genet. 95:992-996.

Crane, M.B. and D. Lewis. 1942. Genetical studies in pears. III. Incompatibility and sterility. J. Genet. 43:31-42.

Darlington, C.D. and L.F. La Cour. 1942. The handling of chromosomes. Macmillan, New York.

de Nettancourt, D. 2001. Incompatibility and incongruity in wild and cultivated plants. 2nd ed. Springer-Verlag, Berlin.

de Wet, J.M.J. 1980. Origins of polyploids, p. 3-16. In: W.H. Lewis (ed.). Polyploidy: Biological relevance. Plenum Press, New York.

Gairdner, A.E. 1926. Campanula persicifolia and its tetraploid form, 'Telham Beauty'. J. Genet. 16:341-351.

Grant, B.R. and P.R. Grant. 1981. Exploitation of Opuntia cactus by birds of the Galápagos. Oecologia (Berlin) 49:179-187.

Hames, B.D. 1981. An introduction to polyacrylamide gel electrophoresis, p. 186. In: B.D. Hames and D. Rickwood (eds.). Electrophoresis of proteins: A practical approach. IRL Press Ltd., Oxford, United Kingdom.

Harlan, J.R. and J.M.J. de Wet. 1975. On Ö. Winge and a prayer: The origins of polyploidy. Bot. Rev. 41:361-390.

Jackson, R.C. 1976. Evolution and systematic significance of polyploidy. Annu. Rev. Ecol. Systematics 7:209-234.

Leuenberger, B.E. 1986. Pereskia (Cactaceae). Mem. N.Y. Bot. Garden 41:1141.

Lewis, D. 1947. Competition and dominance of incompatibility alleles in diploid pollen. Heredity 1:85-108.

Lewis, D. and I. Modlibowska. 1942. Genetical studies in pears. IV. Pollen-tube growth and incompatibility. J. Genet. 43:211-222.

Li, W., G.P. Berlyn, and P.M.S. Ashton. 1996. Polyploids and their structural and physiological characteristics relative to water deficit in Betula papyrifera (Betulaceae). Amer. J. Bot. 83:15-20.

Lichtenzveig, J., S. Abbo, A. Nerd, N. Tel-Zur, and Y. Mizrahi. 2000. Cytology and mating systems in the climbing cacti Hylocereus and Selenicereus. Amer. J. Bot. 87:1058-1065.

Martin, F.W. 1959. Staining and observing pollen tubes in the style by means of fluorescence. Stain Technol. 34:125-128.

Mauseth, J.D. 1978a. An investigation of the morphogenetic mechanisms which control the development of zonation in seedling shoot apical meristems. Amer. J. Bot. 65:158-167.

Mauseth, J.D. 1978b. An investigation of the phylogenetic and ontogenetic variability of shoot apical meristems in the Cactaceae. Amer. J. Bot. 65:326-333.

Mizrahi, Y., A. Nerd, and P.S. Nobel. 1997. Cacti as crops. Hort. Rev. 18:291319.

O'Leary, M.C. and T.H. Boyle. 1998a. Segregation distortion at isozyme locus Lap-1 in Schlumbergera (Cactaceae) is caused by linkage with the gametophytic self-incompatibility $(S)$ locus. J. Hered. 89:206-210.

O'Leary, M.C. and T.H. Boyle. 1998b. Inheritance and linkage relationships of isozymes in Easter cactus. J. Amer. Soc. Hort. Sci. 123:98-103.

O'Leary, M.C. and T.H. Boyle. 1999. Cultivar identification and genetic diversity within a Hatiora (Cactaceae) clonal germplasm collection using isozymes. J. Amer. Soc. Hort. Sci. 124:373-376.

Pandey, K.K. 1956. Incompatibility in autotetraploid Trifolium pratense. Genetics 41:353-366.

Pandey, K.K. 1968. Colchicine-induced changes in the self-incompatibility behaviour of Nicotiana. Genetica 39:257-271.

Parks, C.A. 2002. Chromosome numbers and pollen cytology in Hatiora and Schlumbergera (Cactaceae). MS thesis. Univ. Mass., Amherst.

Pinkava, D.J., M.A. Baker, B.D. Parfitt, M.W. Mohlenbrock, and R.D. Worthington. 1985. Chromosome numbers in some cacti of western North America. V. Systematic Bot. 10:471-483.

Pinkava, D.J., L.A. McGill, T. Reeves, and M.G. McLeod. 1977. Chromosome numbers in some cacti of western North America. III. Bul. Torrey Bot. Club 104:105-110.

Pinkava, D.J. and B.D. Parfitt. 1982. Chromosome numbers in some cacti of western North America. IV. Bul. Torrey Bot. Club 109:121-128.

Pinkava, D.J., J.P. Rebman, and M.A. Baker. 1999. Chromosome numbers in some cacti of western North America. VII. Haseltonia 6:32-41.

Remski, M.F. 1954. Cytological investigations in Mammillaria and some associated genera. Bot. Gaz. 116:163-171.

Ross, R. 1981. Chromosome counts, cytology, and reproduction in the Cactaceae. Amer. J. Bot. 68:463-470.

Sanford, J.C. 1983. Ploidy manipulations, p. 100-123. In: J.N. Moore and J. Janick (eds.). Methods in fruit breeding. Purdue Univ. Press, West Lafayette, Ind.

Sax, H.J. 1938. The relation between stomata counts and chromosome number. J. Arnold Arboretum 19:437-441.

Spencer, J.L. 1955. A cytological study of the Cactaceae of Puerto Rico. Bot. Gaz. 117:33-37.

Stout, A.B. and C. Chandler. 1942. Hereditary transmission of induced tetraploidy and compatibility in fertilization. Science 96:257-258.

Tal, M. 1980. Physiology of polyploids, p. 61-75. In: W.H. Lewis (ed.). Polyploidy: Biological relevance. Plenum Press, New York.

Tel-Zur, N., S. Abbo, D. Bar-Zvi, and Y. Mizrahi. 2001. Hybridization between species and genera of fruit-crop vine cacti of the genera Hylocereus and Selenicereus. HortScience 36:441 (abstr.).

Thompson, J.D. and R. Lumaret. 1992. The evolutionary dynamics of polyploid plants: Origins, establishment and persistence. Trends Ecol. Evol. 7:302-306.

Weeden, N.F. and J.F. Wendel. 1989. Genetics of plant isozymes, p. 46-72. In: D.E. Soltis and P.S. Soltis (eds.). Isozymes in plant biology. Dioscorides Press, Portland, Ore.

Weiss, J., A. Nerd, and Y. Mizrahi. 1994. Flowering behavior and pollination requirements in climbing cacti with fruit crop potential. HortScience 29:1487-1492. Wendel, J.F. and N.F. Weeden. 1989. Visualization and interpretation of plant isozymes, p. 5-45. In: D.E. Soltis and P.S. Soltis (eds.). Isozymes in plant biology. Dioscorides Press, Portland, Ore.

Werdermann, E. 1939. Zur Neuheit-Prüfung vorgelegte Züchtungen. Kakteenkunde 1:10-11. 